\title{
Research on Integrated System for Civil Aviation Runway Excursion Prevention
}

\author{
Zhi-Hui Xie, Dong-Bin Li \\ Civil Aviation Management Institute of China, Beijing, China \\ E-mail: xzh602@aliyun.com, lidongbin@camic.cn
}

\begin{abstract}
According to the analysis of runway excursions incident data of China and world runway excursions prevention experience, this article present the importance of runway excursions prevention work in today's civil aviation safety management. Base on the analysis of domestic runway excursions incident data, this article summarize the characters of runway excursion incidents, and emphasize that runway excursion prevention should pay more attention to the potential hazard and analysis. So this article provides a potential hazard analysis model. Based on this model, the article give a framework of integrated runway excursions prevention system, and describe the levels and functions of the system, and give the suggestions on how to perform runway excursion prevention work according to the systematic framework.
\end{abstract}

Keywords-Runway Excursions Prevention; Potential Failure Analysis; Integrated Prevention System; Systematic Planning; Coordination

\section{INTRODUCTION}

In the ten-year period from 2005 to 2014 , the total number of aircraft operations on China's civil aviation airports kept steadily increasing. The total number of aircraft movements on China's civil airports increased from 3.0565 million by the end of 2005 to 7.933 million in 2014, with an average annual growth rate of $9.23 \%$. The number of China's transportation airports increased from 142 in 2005 to 202 in 2014, with a growth rate of $42.25 \%$. The traffic of several large China's airports, such as Beijing Capital Airport, Shanghai Pudong Airport and etc., have already ranked among the busiest airports in the world, while the number of China's small and medium size civil airports kept rapidly increasing.

With the growth both of the quantity and air traffic of the China's civil aviation airports, the runway operational environment of aircraft became more and more complicated.
There were $14 \%$ fatal accidents involved runway excursion in the top-10 consequences of all worldwide fatal accidents for the ten-year period from 2002 to 2011[1]. Although none of the accidents was caused by runway excursion in China civil aviation industry from year 2005 to 2014, but there was an overall increasing trend in the number of incidents involved runway excursion. Runway excursion prevention should dominate in China civil aviation runway safety management field. Therefore, the establishment of an Integrated System for Civil Aviation Runway Excursion Prevention is proposed here in this paper, to maintain and promote the runway safety level of China civil aviation industry.

\section{II.NECESSITY OF ESTABLISHING THE INTEGRATED SYSTEM FOR CIVIL AVIATION RUNWAY EXCURSION PREVENTION}

\section{A. Heavy tasks of runway excursion prevention faced by China civil aviation industry}

Task of runway excursion prevention faced by China civil aviation industry became heavier. According to the data provided by Aviation Safety Net of China, there were a total 72 runway excursion occurrences took place in China from 2005 to 2014. During last ten years, the number of the runway excursion occurrences fluctuated between 5 times per year to 11 times per year, showing a slow increasing trend. With the linear regression analysis, the number of the runway excursion incidents increased by $27 \%$, as Fig. 1 shows. The number of runway excursion occurrences didn't decrease obviously during last ten years; otherwise, the average value of runway excursion incidents had an increasing trend in recent five years. It is essential to give adequate attention to runway excursion prevention by China civil aviation industry. 


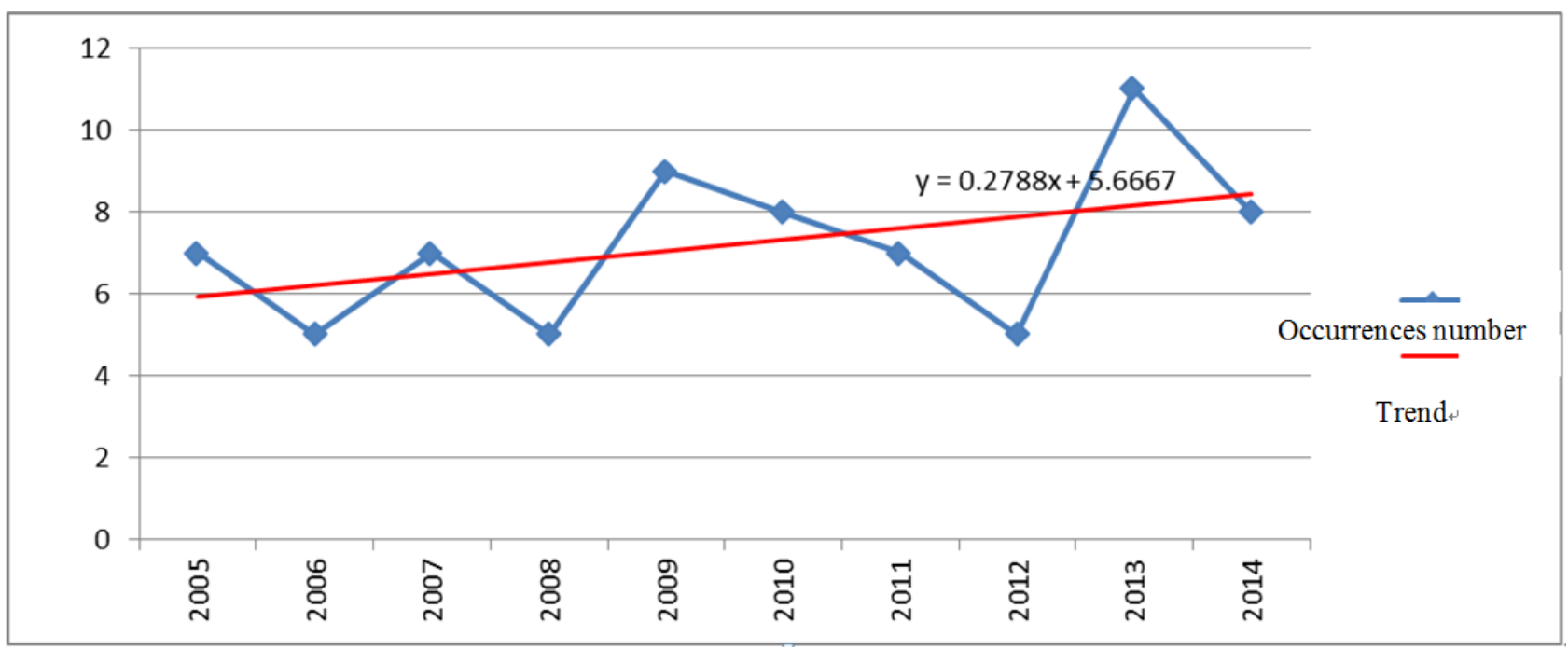

Figure.1. Total number and trend line of runway excursion occurrences took place in China from 2005 to 2014

B. Comprehensive collaboration should be setup for runway excursion prevention, which should be enhanced at this period.

Since the releases of "Runway Safety Plan of China Civil Aviation" by CAAC headquarter in 2008, special agencies/organizations responsible for runway safety had been assigned by China's civil aviation regional administrations and civil aviation transportation airports around the nation [2]. With runway safety management practices, runway safety management agencies/organizations in field had gathered numerous runway safety data, and gained management experiences as well. But almost all of these data and experiences were focused on runway incursion, only a small part of them were related to runway excursion prevention. Therefore, integrated collaboration mechanism should be established to promote the systematical progress of runway excursion prevention of civil aviation.

\section{Civil aviation advanced countries and regions have already paid increased attention to runway excursion prevention.}

As the transformation of the civil aviation operation environment of aircraft and the insight research on runway safety, runway excursion prevention had become gradually the priority of the worldwide runway safety fields. CAA UK released Worldwide Fatal Accident Review 2002 to 2011(CAP 1036) in Jun, 2013. The statistics in this report showed that $14 \%$ fatal worldwide accidents were caused by runway excursion [1]. In 2013, EUROCONTROL published European Action Plan for the Prevention of Runway Excursions (Ver 1.0). So, the runway excursion prevention has been the common concerns of the worldwide civil aviation industry safety management. It has been the international trend that integrated planning and collaborative establishing the runway excursion prevention system from the perspective of national or regional government aviation industry management.

\section{CONCEPT AND CHARACTERISTICS OF RUNWAY EXCURSION OCCURRENCES}

\section{A. Concept of runway excursion occurrences}

A runway excursion is defined as "an event in which an aircraft veers off or overruns the runway surface during either takeoff or landing" [4].

\section{B. Characteristics of runway excursion occurrences}

Compared with other kinds of runway unsafety occurrences, there are three significant characteristics of runway excursion occurrences, which include complex influencing factors, high severity of consequences and latent failures hard to detect.

\section{1) Complex influencing factors}

There are so many different influential factors which resulted in runway excursion occurrences. According to the findings of the previous unsafe occurrences investigation, there are two kinds of factors, which are causual factors and circumstantial factors, for all occurrences with a "runway excursion" consequence. Causual factors of runway excursion occurrences were always related with flight crews handling. However, exploring the essential circumstantial factors resulted in runway excursion occurrences, a very wide range of factors were presented. For example, analysis of global accident data from 2002 to 2011 showed that although the causual factors of runway excursion accidents were closely related with the flight crew preparation and handling, a very wide range of circumstantial factors, such as inadequate time to allocated task by company, weather general, indaquate regualtory oversight,birds/wildlifes, design of RESA, intersecting runways, taxiways layout and etc., were related to the accidents with a runway excursion consequence[3]. It is obvious that the runway excursion prevention has a comphensive characteristic. 


\section{2) High severity of consequence}

As to the consequences of runway excursion occurrences, runway excursion occurrences have the feauture of high severity of consequences [7]. According to staticstics of runway excursion occurrences consequance severity from Jan, 2003 to Aug, 2013 published by CAAC, serious incidents caused by runway excursion acounted for $32 \%$, and $41 \%$ for incidents, as shown in Fig. 2. Once the runway excursion took place, incidents became the high probability events. Compared with other kinds of runway unsafe occurrences, such as runway incursion occurrences, runway excursion occurrences always bursted out in a sudden with high serious consequences.

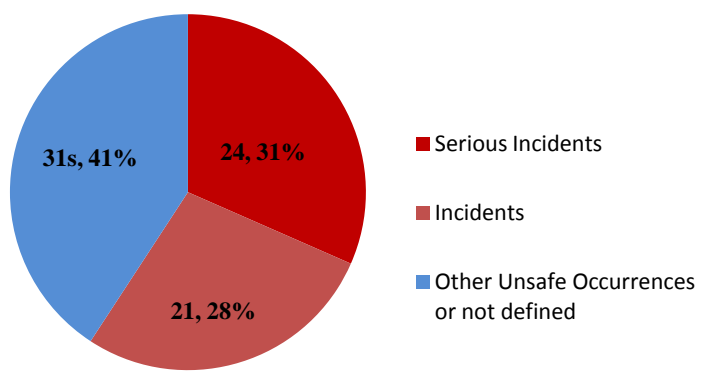

Figure.2. China civil aviation runway excursion incidents consequences severity classification statistics from Jan, 2003 to Aug, 2013

\section{3) Latent failures hard to detect}

According to the above analysis of China's civil aviation runway excursion incidents statistics, the proportions of runway excursion serious incidents, incidents and other unsafe occurrences presented the triangular balance, without any obvious progressive relationship. Therefore, in order to prevent higher level incidents, even the accidents occurred, insight research on latent failures of the lower level unsafe occurrences should be carried out. More emphasis should be placed on the data mining and data analysis of latent failures for the purpose of runway excursion prevention. It is essential for the effectiveness of runway excursion prevention to carry out the research hierarchically and deeply on the runway excursion failure factors, detailed analysis shown in Fig. 3.

The active failures leading to runway excursion unsafe occurrences can be attributed to the aircraft operation factors, such as the flight crew operational failure, inadequate crew training, inadequate crew pre-flight preparation, and etc.. But, more latent failures, including the support from airports operators, air traffic controls and the aircraft manufactures, the coordination among the relevant operational organizations, industry safety supervisions, the scientific of the industry standards, and etc., are difficult to find out and be resolved.

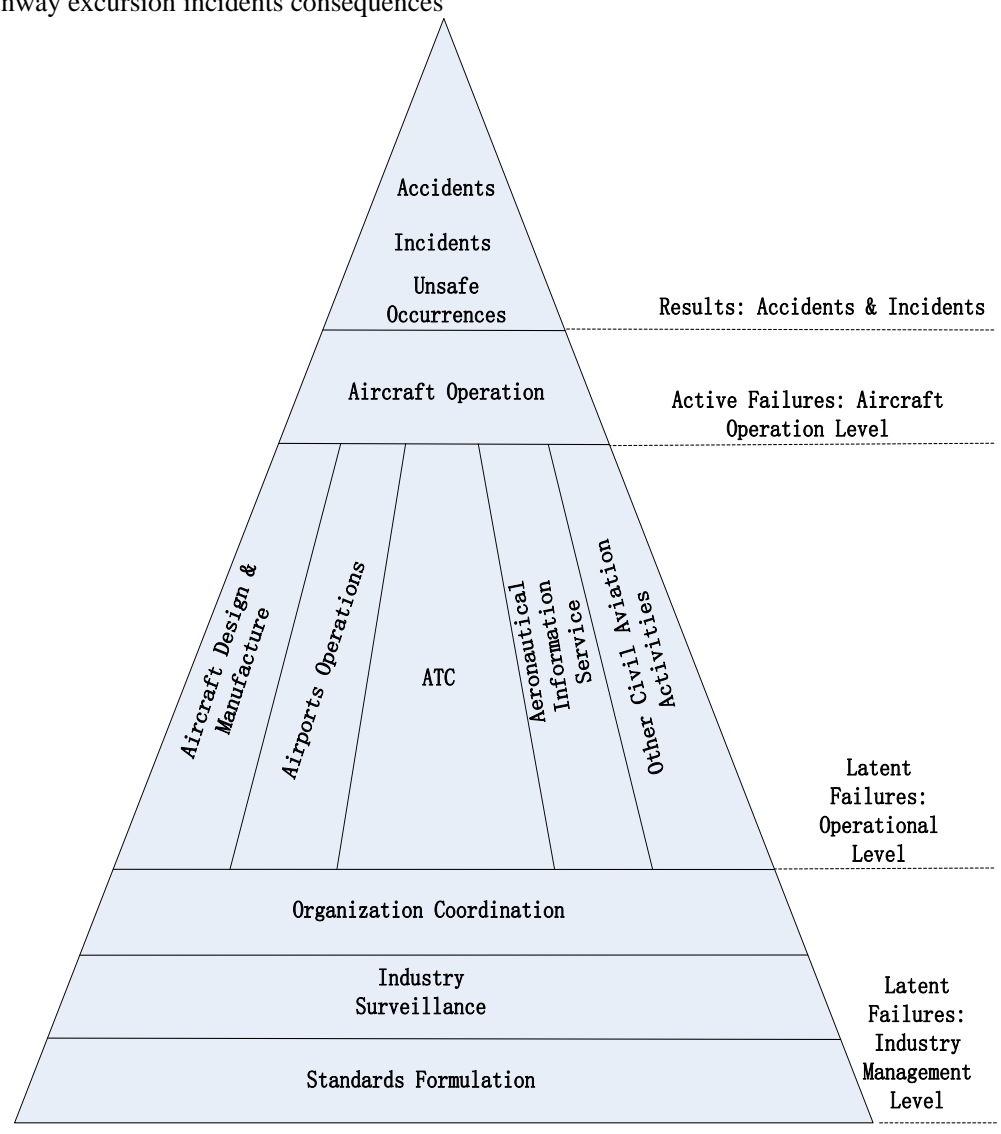

Figure.3. Hierarchical analysis of failures resulted in runway excursion incidents 


\section{DESIGN OF INTEGRATED SYSTEM FOR CIVIL AVIATION RUNWAY EXCURSION PREVENTION}

\section{A. Structure of Integrated System for Civil Aviation Runway Excursion Prevention}

According to the analysis of domestic and international runway excursion accidents and incidents statistics, integrating the international runway excursion prevention experiences and the analysis model of latent failures resulted in runway excursion hazards designed in this paper, it is found that systematical planning and organizing should be carried out by multi-level expectively in order to implement comprehensive prevention strategies to achieve the goal of runway excursion prevention.

Therefore, it is recommended that the establishment of corresponding prevention system should be based on the perspective of the governmental industry management, to achieve a well-planned, multi-level, comprehensive prevention and control capabilities. The composition and functions of the system were shown as Figure. 4.

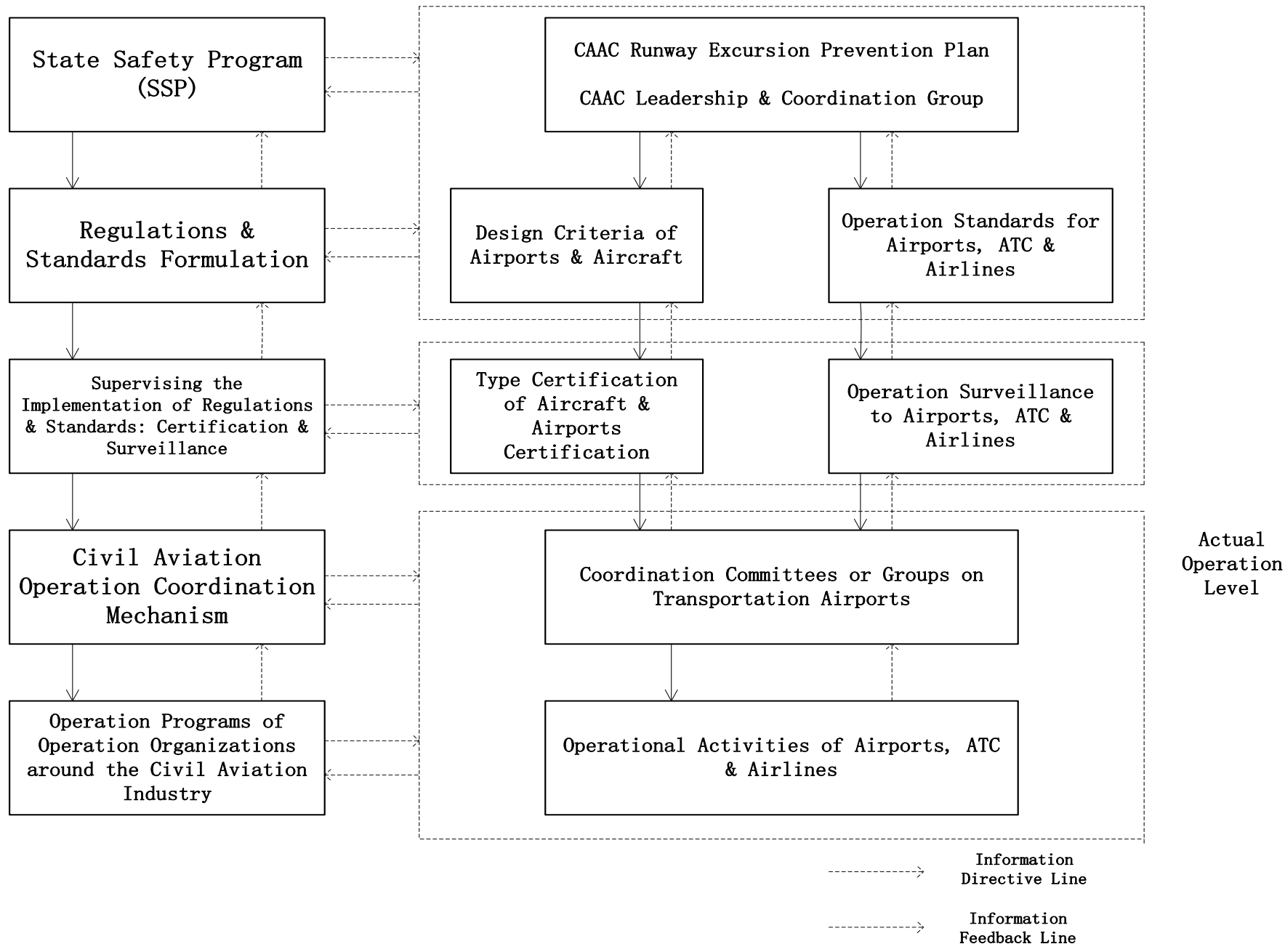

Figure.4. Map of integrated system for civil aviation runway excursion prevention

1) Master planning and decision-making level

It is recommended by ICAO in its Safety Management Manual (ICAO Doc 9859) that the member states should establish their own State Safety Program (SSP) to manage civil aviation safety risks effectively. As to the master planning of civil aviation industry management, the requirements of managing runway excursion risks should be adopted in SSP first, to include the runway excursion risks 
management into the scope of the SSP. Secondly, the corresponding plan should be made by the civil aviation industry management. All domestic and international experiences from civil aviation industry showed that, it would provide the organizational guarantee and resource support to the runway excursion prevention that well-planned establishment and implementation of "runway excursion prevention plan" throughout the whole civil aviation industry.

2) Supervision and inspection level

On the basis of consummate regulations and standards, it is necessary for the civil aviation safety regulators to surveillance the aircrafts operations, the airports operations and the activities of air traffic services. The airports certification standards and aircraft type certification criteria should be updated and refined accordingly, since runway excursion prevention issues should be put into consideration at the very beginning design stage of airports and aircraft.

On the other hand, continuous supervision and inspection should be carried out by the civil aviation safety regulatory authorities to verify that the applicable regulatory requirements on runway excursion prevention measures have been implemented appropriately by airports operators, aircraft operators and air navigation services providers.

Furthermore, as the SMS had been established by operational organizations respectively, safety auditing should be carried out by civil aviation safety regulatory authorities to understand the operational organizations' safety status, to evaluate their safety level achieved, and to verify the implementation of applicable safety and regulatory requirements. And the runway excursion risks management of the operational organizations could be evaluated during this kind of audit.

\section{3) Practical/actual operation level}

In addition to the runway excursion prevention coordination mechanism setup by the civil aviation industry regulator headquarter, the runway excursion prevention coordination organizations should be setup respectively in the regions throughout the nation in the practical/actual operation level. For example, such kind of coordination organization could be setup on the basis of the existing runway safety management committee or coordination team at the transportation airports, acting as the executive body of the civil aviation industry runway safety management institution, whose function is enhancing the cooperation mechanism on runway excursion prevention among the local airports operators, aircraft operators, and the air traffic services providers.

\section{B. Continuous management of Integrated System for Civil Aviation Runway Excursion Prevention}

It is a long-term process to establish the runway excursion prevention planning system, during which the follow-up and evaluation of the implementation and the dynamical adjustment mechanism of the planning should be established.

First of all, once the civil aviation runway excursion plan has been published by civil aviation industry regulatory, the follow-up mechanism about the implementation of the plan should be setup during the process of the plan implementation. It should be carried out according to the schedule defined in the plan to inspect and track the works of the different departments of the CAAC and the operational organizations.

Secondly, the mechanism of dynamic evaluation of the systematic risks of the runway excursion should be setup. Besides the regular assessment of the relevant risks, the corresponding assessment activities should be carried out in the light of special issues.

Thirdly, the evaluation and update mechanism should be established to assess and update the runway excursion prevention plan at a regular interval (every 3 or 5 years).

\section{REFERENCES}

[1] UK Civil Aviation Authority, Global Fatal Accident Review 2002 to 2011, 2013.

[2] CAAC, Civil Aviation Runway Safety Plan, 2008.

[3] HU Jianwei, LEI Ming, RU Hengxin, "Preventing 'runway excursion' to Ensure 'runway safety', China Civil Aviation, pp.57, May 2010.

[4] EUROCONTROL, "European Action Plan for the Prevention of Runway Excursions", 2013.

[5] LI Xiaoyan, "Statistical Analysis of Worldwide Runway Excursion Accidents of Commercial Jets in the Last Decade", China Civil Aviation, pp.37-39, Sep. 2009.

[6] HUO Zhiqin, RU Yi, HAN Songchen, "Analysis Model of Transport Aircraft Veering-off Runway during Landing Phase", Journal of Southwest Jiaotong University, ,pp.896, Oct., 2012.

[7] Huo Zhiqin, "Statistical Analysis on Runway Excursion of Transport Aircraft in China", Journal of Safety Science and Technology, pp.129, June, 2012.

[8] FAA, 2012-2014 Runway Safety Plan.

[9] ICAO, Safety Management Manual (SMM), 2009.

[10] ICAO, Safety Management Manual (SMM), 2006.

[11] FSF, Strategy on Runway Excursion Precaution, 2009. 